\title{
A STEADY STATE HYDRAULIC MODEL OF A KARST AQUIFER
}

\author{
STACIONARNI HIDRAVLIČNI MODEL KRAŠKEGA \\ VODONOSNIKA
}

\author{
Janez TURK ${ }^{1}$
}

\begin{abstract}
UDC 556.34

Janez Turk: A steady state hydraulic model of a karst aquifer

It is known, that $90 \%$ or even more of underground water flows through large conduits. Restrictions and siphons represent only small percentage of karstic aquifer. But because of them, conduits, which transmit water, are only partly accessible. Difficult access is a reason why many water transmissions have not been explored yet. Because of this, geometry and length of all underground conduits is not known, it can be only predicted. In such a case processes of water flow in karstic conditions are more easily predictable by modeling. Basic physical models are usually used. They are based on the conduit permeability of karst water. We assume conduits with different dimensions, smaller usually presenting areas of full pipe flow (under pressure) and larger open channel flow. We were interested in the hydraulic conditions, when does the change from open channel to full pipe flow occur and when does underground flow from main conduit divide into two neighbouring conduits. The response of a karst aquifer to a flood pulse was not studied in our model, but we observed its behaviour during a constant increase of recharge into the karstic underground.

Key words: karst modeling, underground karst system, open channel flow, full pipe flow.
\end{abstract}

\author{
Izvleček \\ UDK 556.34 \\ Janez Turk: Stacionarni hidravlični model kraškega vodonos- \\ nika
}

Dejstvo, da se kar $90 \%$ ali celo več podzemne kraške vode pretaka po velikih kraških kanalih je splošno znano. Zožitve v obliki sifonov predstavljajo le manjši delež kraških prevodnikov. Vendar so zaradi njihovega pojavljanja kraški kanali, ki prevajajo vodo le deloma dostopni. Zaradi težavnega prehoda prek sifonov veliko kraških kanalov še ni bilo raziskanih. Geometrija in dolžina vseh kraških prevodnikov torej ni znana, lahko jo le predvidevamo. $\mathrm{V}$ takšnem primeru je procese pretakanja podzemne kraške vode najenostavneje ugotavljati $\mathrm{z}$ modeliranjem. Večinoma se uporablja enostavne fizikalne modele, ki temeljijo na kanalski prevodnosti kraške vode. Predpostavimo kanale različnih dimenzij, vmesni manjši običajno predstavljajo območja toka pod tlakom, večji kanali pa se obnašajo kot rezervoarji. V našem modelu smo se osredotočili na robne pogoje, ob katerih pride do spremembe toka s prosto gladino $\mathrm{v}$ tok pod tlakom in pogoje ob katerih se podzemni tok razdeli med dva sosednja kanala. V obravnavanem modelu nismo ugotavljali odziva kraškega vodonosnika na nek poplavni sunek, pač pa njegovo obnašanje ob konstantnem povečevanju dotoka $\mathrm{v}$ kraško podzemlje.

Ključne besede: kraško modeliranje, podzemni kraški sistem, tok s prosto gladino, tok pod tlakom.

${ }^{1}$ Karst Research Institute SRC-SASA, Titov trg 2, 6230 Postojna, Slovenia; e-mail: janez.turk@zrc-sazu.si

Received/Prejeto: 15.01.2007 


\section{INTRODUCTION}

Characterisation of karst aquifer is a difficult task, because the position and geometry of conduit network which transmits most of groundwater is not known. If the geometry is at least approximately known or can be predicted and the recharge into the underground system can be measured (or estimated) we can make a simplified model.

Models can be imaginary or a simplification of realistic conditions in the karst underground. We should be aware that all estimations can be very approximate and results are not always reliable. The easiest way to reconstruct underground karst water flow is to use models. There are two major approaches:

- Global methods are based on the analysis of spring discharge and precipitation time series. These data reflect hydraulic characteristics of underground system. But the spatial heterogeneity and structure of karst underground is neglected, so only qualitative interpretation is possible (Sauter 2005)

- Distribute methods incorporate two concepts. First is a discrete concept, which describes flow within networks of fractures or conduit (Sauter 2005). This method assumes different structures of karst aquifer and a simplified geometry of conduits. It can be used to assume the amount of underground water flow or aquifer's response to a certain storm event (Halihan et al., 1998). The discrete concept was used in our model. Water flow in our model is treated as one-dimensional and conduits have different permeability.

Second is a continuum concept and it treats heterogeneities in terms of effective model parameters and their spatial distribution. A hybrid model is a combination of both concepts (Sauter 2005).

Before starting any modeling some important features of karst aquifer should be considered: recharge, discharge, geometry of the system, permeability, friction factor and boundary conditions (White 2003 \& Springer 2003 \& Kiraly 2002).

- Recharge can be allogenic from the sinking streams, autogenic through the epikarst or combination of both (Ford \& Williams 1989).

- Discharge can be measured before a river sinks underground. We should be aware of possible water losses into larger or smaller fractures inside the cave system, recharges as underground tributaries and autogenic infiltration (Springer 2003).

- Geometry of the model is simplified. Karst water flows through a system of conduits and fractures which have different diameters. Conduit shapes are very irregular and it is almost impossible to predict them. Constrictions between conduits may cause back flooding. Conduits may divide or combine into more or one.
- Permeability is linked with the porosity. In general we distinguish inter-granular, fracture and conduit permeability. More than $90 \%$ of underground karst waters flow through large conduits (Bonacci 1987).

- Friction happens within water flow and at the contact of water and bedrock. The higher the friction, the lower are flow velocities. Cave walls have a friction factor between 0.028 and 0.13 , according to measurements in many caves (Springer 2003). It is linked also with lithology. Inside one cave system, the friction factor is very variable parameter.

- Boundary conditions which affect discharge flow regime in karst underground are hydraulic head and recharge (Kiraly 2002).

A brief review of the literature indicates, that most models were based on an assumption of water flow through conduits with different dimensions (system consisting of large conduits and restrictions between them). For example, Halihan and Wicks (1998) interpret large conduits as reservoirs with free water surface. Permeability of the whole system is determined by the smallest constriction, through which water is transmitted under pressure (as a full pipe flow). The purpose of such models is to interpret flood response of karst aquifer.

Campbell et al. (2002) used a computer program Storm water management model (EPA, SWMM) to calculate energy losses in the karst underground. They considered both full pipe flow and open channel flow.

The aim of this paper is to demonstrate different possible flow scenarios within karst aquifer based on the simple model of discrete conduits and reservoirs. The model can be divided into two sub-domains. Flow from lake $(\mathrm{A})$ to the underground chamber (B) and to the wire (see chapter "model description and data") can be considered as an input to the lower conduit system. Second sub-domain represents flow from the wire to the conduit system 2-3-4 and 5-6 (Fig. 1), where we assume three different flow scenarios:

- open channel flow in primary conduits

- full pipe flow in primary conduits

- full pipe flow in all conduits

The geometry of the system is assumed to be constant, but hydraulic parameters are variable. Relations between water levels (of the lake and underground "reservoirs") and discharge were observed. In three different scenarios, attention will be given to the behaviour of underground water flow through large conduits with different diameters at different hydraulic conditions (hydraulic gradient and discharge) 


\section{MODEL DESCRIPTION AND DATA}

The model represents a system of underground conduits between higher located lake and karst spring (Fig.1). Underground conduits are supplied by the lake water. The sinkhole is active all the time in our model, because lake has a positive water balance.

Lake water, sinking into the underground flows first through a conduit until it reaches an underground chamber. Water balance of the lake enables full pipe flow through the first conduit.

Water stagnates in the underground chamber. Some rocky barrier, such as a rockfall, causes water stagnation. As a result, an underground karst lake forms. The barrier behaves like a weir. It is long enough, that water cannot reach the chamber's ceiling even during the highest dis- conduit is secondary and it is active only during episodic water conditions. Both conduits join together before the spring. The water emerges at altitude, which is $50 \mathrm{~m}$ lower than the bottom of the lake.

The hydraulic model has geometry precisely as possible determined. All parameters and their typical values are given in Tab 1. Geometrical symbols are also shown in Fig. 1, where L is length and $\Phi$ is a diameter of conduit.

The model tried to represent useful usage of hydraulic equations in karst underground. Our model is a fiction, but anyway very similar features between two karstic poljes are possible. There are a few connected poljes in Dinaric karst. The most famous Slovenian seasonal lake

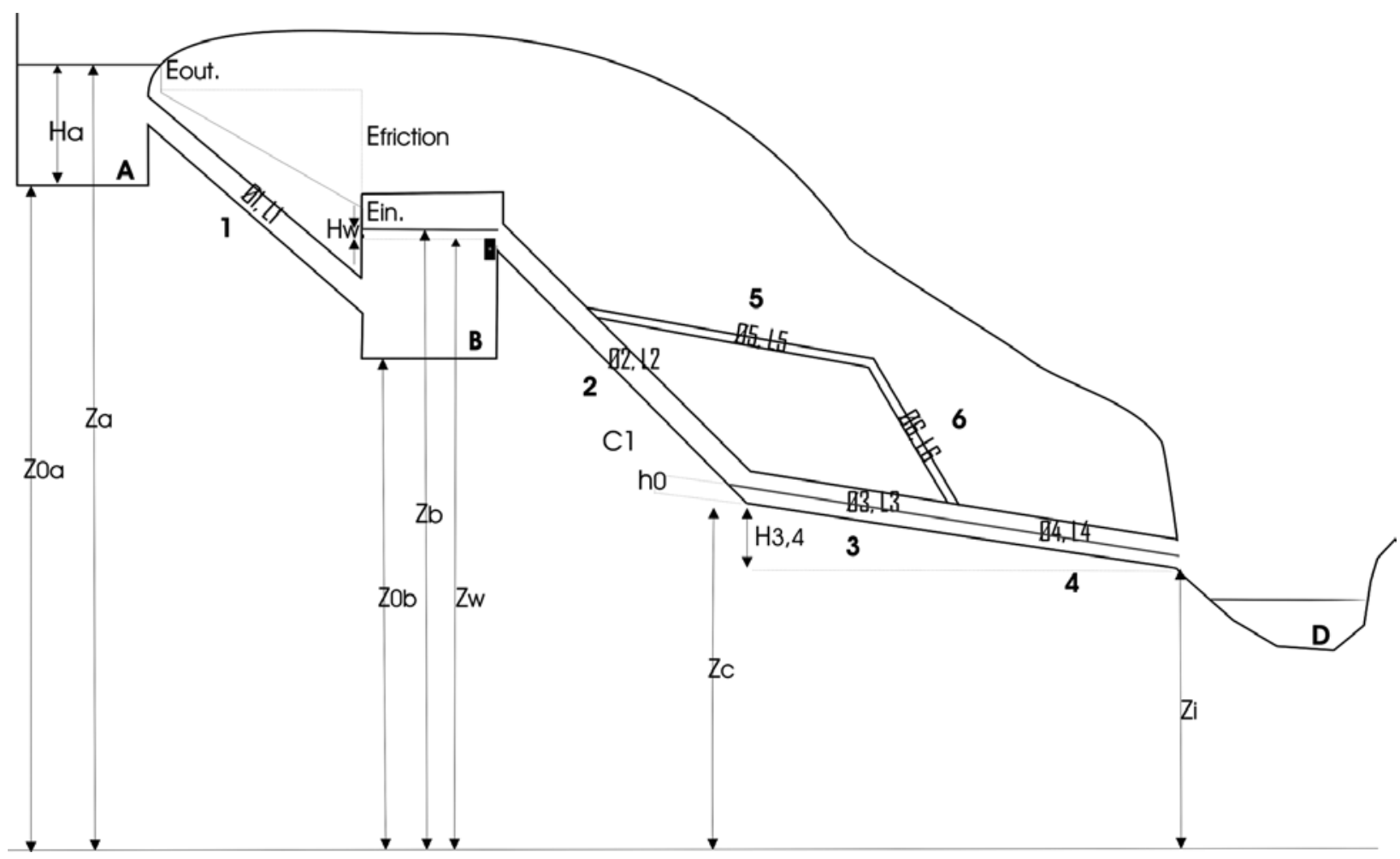

Fig. 1: Shematic review of underground system.

charges. The water has free surface in the underground chamber during any discharge conditions.

The water spills over the barrier (weir) into the next conduit. It splits into two parts of which the lower conduit is the main and is active all the time. The upper is in Cerkniško polje. There are a lot of swallow holes at the bottom of the Cerknica lake and water emerges in many springs few tenth kilometers away, at the contact of carbonate Jurassic rocks with Quaternary sediments which fill the tectonic basin of Ljubljana moor. 


\begin{tabular}{|l|l|}
\hline \multicolumn{2}{|l|}{ GEOMETRICAL DATA } \\
\hline $\mathrm{Z}_{\mathrm{a}-\text { min. }}[\mathrm{m}]$ & 102 \\
\hline $\mathrm{Z}_{\text {oa }}[\mathrm{m}]$ & 60 \\
\hline $\mathrm{H}_{\mathrm{a}}[\mathrm{m}]$ & 42 \\
\hline $\mathrm{Z}_{\mathrm{b}}[\mathrm{m}]$ & $\mathrm{Z}_{\mathrm{w}}+\mathrm{H}_{\text {weir }}$ \\
\hline $\mathrm{Z}_{\text {ob }}[\mathrm{m}]$ & 30 \\
\hline $\mathrm{Z}_{\mathrm{w}}[\mathrm{m}]$ & 52 \\
\hline $\mathrm{Z}_{\mathrm{c}}[\mathrm{m}]$ & 12 \\
\hline $\mathrm{Z}_{\text {split }}[\mathrm{m}]$ & 42 \\
\hline$\Delta \mathrm{H}_{\text {split }}[\mathrm{m}]$ & 30 \\
\hline$\Delta \mathrm{H}_{3,4}[\mathrm{~m}]$ & 2 \\
\hline$\Delta \mathrm{H}_{\text {split }}[\mathrm{m}]$ & 30 \\
\hline$\Phi_{1}[\mathrm{~m}]$ & 3 \\
\hline $\mathrm{L}_{1}[\mathrm{~m}]$ & 200 \\
\hline$\Phi_{2}[\mathrm{~m}]$ & 5 \\
\hline $\mathrm{L}_{2}[\mathrm{~m}]$ & 200 \\
\hline $\mathrm{L}_{\text {split }}[\mathrm{m}]$ & 150 \\
\hline$\Phi_{3}[\mathrm{~m}]$ & 5 \\
\hline $\mathrm{L}_{3}[\mathrm{~m}]$ & 150 \\
\hline$\Phi_{4}[\mathrm{~m}]$ & 5 \\
\hline $\mathrm{L}_{4}[\mathrm{~m}]$ & 150 \\
\hline$\Phi_{5}[\mathrm{~m}]$ & 3 \\
\hline $\mathrm{L}_{5}[\mathrm{~m}]$ & 150 \\
\hline$\Phi_{6}[\mathrm{~m}]$ & 3 \\
\hline $\mathrm{L}_{6}[\mathrm{~m}]$ & 150 \\
\hline $\mathrm{trapezium}$ & \\
\hline $\mathrm{h}[\mathrm{m}]$ & 5 \\
\hline $\mathrm{D}[\mathrm{m}]$ & 2 \\
\hline $\mathrm{B}_{2}[\mathrm{~m}]$ & 2 \\
\hline $\mathrm{m}$ & 0.4 \\
\hline
\end{tabular}

Values of friction factors are given in Tab. 1.

\section{FLOW FROM THE LAKE TO THE WEIR}

Domain can be considered as a system of two connected reservoirs. Flow between the reservoirs is full pipe, because water level of the lake is all the time above the sinkhole according to our hypothesis (Fig. 1).

In this scenario, water level of the lake and height of water spilling over the weir at some variable discharges were calculated. Flow between two "reservoirs" and spilling over the weir are independent on further hydraulic conditions and type of flow in conduits (2-3-4) or (5-6).

First some initial discharge must be chosen or calculated, which will be arbitrary increased. We will then calculate water height at weir $\left(\mathrm{H}_{\text {weir }}\right)$ and losses in the conduit. Finally water level of the lake ( $\mathrm{Za}$ ) will be calculated.

Relation between discharge $(\mathrm{Q})$ and flow velocity (v) is described by following equation:

$\mathrm{Q}=\mathrm{A} * \mathrm{~V}=\pi *\left(\frac{\phi}{2}\right)^{2} * \mathrm{~V}$

A - cross section area of conduit filled with water $\left[\mathrm{m}^{2}\right]$ $\Phi$ - pipe diameter $[\mathrm{m}]$

The system of flow between lake (A) into underground chamber (B) through conduit (1) is expressed by Bernoulli's equation:

$\frac{\mathrm{p}_{1}}{\rho \mathrm{g}}+\mathrm{h}_{1}+\frac{\mathrm{v}_{1}^{2}}{2 \mathrm{~g}}=\frac{\mathrm{p}_{2}}{\rho \mathrm{g}}+\mathrm{h}_{2}+\frac{\mathrm{v}_{2}^{2}}{2 \mathrm{~g}}+\sum(\Delta \mathrm{E})$

Tab. 1

\section{SCENARIOS AND EQUATIONS}

First, some estimations should be done. Conduit roughness coefficient was estimated as $\mathrm{Ng}=0.03 \mathrm{~s} / \mathrm{m}^{1 / 3}$ (Steinman 1999 \& Rossman 2004). We assume limestone walls with a relative high roughness.

Friction factor $(\lambda)$ depends on conduit diameter and roughness coefficient $(\mathrm{Ng})$. We use connection between friction factor $(\lambda)$ (after Darcy-Weissbach) and Manning's roughness coefficient $(\mathrm{Ng})$ :

$\mathrm{p}$ - hydrostatic pressure $\left[\mathrm{Pa}=\mathrm{N} / \mathrm{m}^{2}\right]$

$\rho$ - density $\left[\mathrm{kg} / \mathrm{m}^{3}\right]$

$\mathrm{g}$ - gravitational acceleration $=9,8 \mathrm{~m} / \mathrm{s}^{2}$

$\mathrm{h}$ - height above arbitrary comparative surface $[\mathrm{m}]$ $\Sigma(\Delta \mathrm{E})$ - sum of all energy losses.

Hydrostatic pressure exists only in reservoirs completely filled with water, otherwise $\frac{\mathrm{p}}{\rho \mathrm{g}}=0$.

Therefore the difference between the potentials in the lake and reservoir is equal to the energy losses in the conduit (Fig. 1):

$\mathrm{Z}_{\mathrm{a}}=\mathrm{Z}_{\mathrm{b}}+\Delta \mathrm{E}$ 
where:

$$
\Delta \mathrm{E}=\Delta \mathrm{E}_{\text {inf low }}+\Delta \mathrm{E}_{\text {friction }, 1}+\Delta \mathrm{E}_{\text {outflow }}
$$

$\Delta \mathrm{E}$ is energetic loss. We distinguish friction and local losses (local losses occur at every change of streamline: for example at stream expansion and narrowing, at outflow from a conduit into a larger underground chamber and the opposite, at bends etc.).

Friction losses in the circular conduit are calculated by Darcy-Weissbach equation:

$$
\Delta \mathrm{E}_{\text {friction }}=\lambda \frac{\mathrm{L}}{\Phi} * \frac{\mathrm{v}^{2}}{2 \mathrm{~g}}
$$

$\mathrm{L}$ - pipe length $[\mathrm{m}]$

$\Phi$ - pipe diameter $[\mathrm{m}]$

Hydraulic diameter for circular pipe is considered as $\mathrm{R}=\frac{\mathrm{A}}{\mathrm{P}}=\frac{\Phi}{4}$

$\mathrm{P}$ - perimeter of cross section $[\mathrm{m}]$

Local losses (inflow and outflow) must be added to get total energy losses. These are given by following equation:

$$
\begin{aligned}
& \Delta \mathrm{E}_{\text {local }}=\xi_{\text {local }} * \frac{\mathrm{v}^{2}}{2 \mathrm{~g}} \\
& \xi-\text { coefficient of local loss }
\end{aligned}
$$

The Bernoulli's equation (3) then becomes

$$
\mathrm{Z}_{\mathrm{a}}=\mathrm{Z}_{\mathrm{b}}+\frac{\mathrm{v}^{2}}{2 \mathrm{~g}} *\left(\xi_{\text {inflow }}+\lambda \frac{\mathrm{L}_{1}}{\phi_{1}}+\xi_{\text {outlow }}\right)
$$

where $\xi_{\text {outflow }}=1$ (Steinman 1999)

The level $\mathrm{Z}_{\mathrm{b}}$ in the reservoir (B) equals to $\mathrm{Z}_{\mathrm{w}}+\mathrm{H}_{\text {weir }}$ where the $\mathrm{H}_{\text {weir }}$ is the height of the water at the weir (Fig. 1). To get some basic, initial discharge, we first assume that water level in reservoir (B) increases only until it reaches the top of the weir, therefore $\mathrm{H}_{\text {weir }}=0$ and $\mathrm{Z}_{\mathrm{b}}=\mathrm{Z}_{\mathrm{w}}$. After this presumption, we can use equation (3.2) to calculate velocity (v) and then we use equation (2) to calculate initial discharge $(\mathrm{Q})$. After consideration that $\mathrm{Z}_{\mathrm{b}}=\mathrm{Z}_{\mathrm{w}}$, minimum discharge can be calculated, at some minimum $\mathrm{Z}_{\mathrm{a}}$. All following calculations are based on that minimum discharge.
$\mathrm{Q}_{\min }=16,77 \mathrm{~m}^{3} / \mathrm{s}$ (initial discharge), according to our calculations (respectively rounded up to $16,8 \mathrm{~m}^{3} / \mathrm{s}$ ). Arbitrary values are added up to $\mathrm{Q}_{\min }$. So the discharge is being increased gradually which is a consequence of rising water level of the lake. Discharge through karst conduit (1) increases proportionally with flow velocity (v) (equation 2) along the conduit (1). Consequently water level in the underground chamber (B) is changing. The higher the discharge, the higher is the water level spilling over the weir (equation 4.1). The weir is a barrier (rockfall). Water spills over the barrier into next karst conduit.

Discharge over barrier (weir) is calculated by the equation for a perfect weir. Perfect weir (Fig. 2) can not be flooded by downstream water.

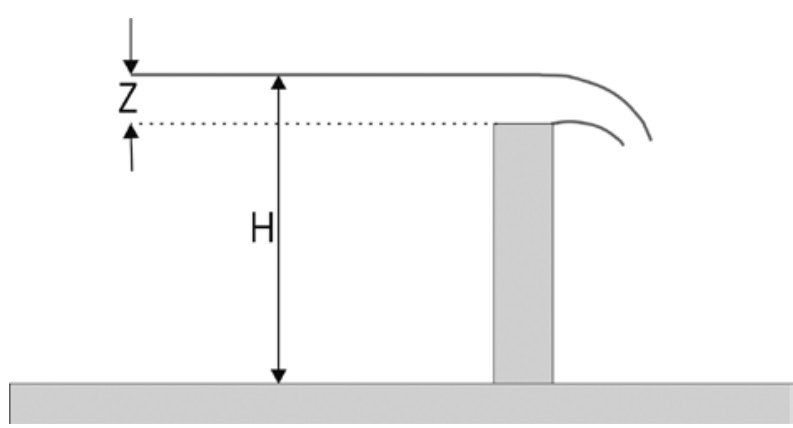

Fig. 2: Sketch of perfect weir.

$\mathrm{Q}=\frac{2}{3} * \mu * \mathrm{~b} * \sqrt{2 \mathrm{~g}} * \mathrm{H}_{\text {weir }}^{2 / 3}$

Where

$\mu$ - weir coefficient (it can be read from tables in the literature)

b - weir width $[\mathrm{m}]$

$\mathrm{H}_{\text {weir }}$ - height of spilling water above the weir [m]

Weir coefficient $\mu$ was estimated to 0.79 (Steinman 1999)

From equation (4.) $\mathrm{H}_{\text {weir }}$ can be expressed:

$\mathrm{H}_{\text {weir }}=\left(\frac{\mathrm{Q}}{\frac{2}{3} * \mu * \mathrm{~b} * \sqrt{2 \mathrm{~g}}}\right)^{3 / 2}$ 
Water level in the underground chamber (value $\mathrm{Z}_{\mathrm{b}}$ ) is:

$\mathrm{Z}_{\mathrm{b}}=\mathrm{Z}_{\mathrm{w}}+\mathrm{H}_{\text {weir }}$

Calculated value $\mathrm{H}_{\text {weir }}$ is put in equation (5) to get level of water in the underground chamber (B) (respectively value $\mathrm{Z}_{\mathrm{b}}$ ) at different discharges. Value $\mathrm{Z}_{\mathrm{b}}$ is put into equation (3.2) to get water level of the lake $\left(Z_{a}\right)$ at different hydraulic conditions. Water level of the lake is the parameter, which has the main influence on discharge variations within the karst underground.

The function of water levels is shown in Fig. 3.

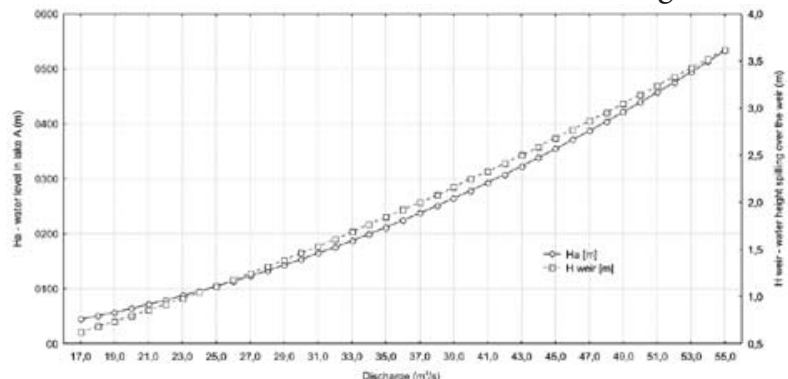

Fig. 3: Relation between water levels $(\mathrm{m})$ and discharge $(\mathrm{m} 3 / \mathrm{s})$.

\section{SCENARIO 1: OPEN CHANNEL FLOW THROUGH CONDUITS (2-3-4) AFTER SPILLING OVER THE WEIR}

In scenario 1 , special interest will be given in transition from open channel flow to full pipe flow and water level heights $\left(h_{0}\right)$ in conduits 3 and 4 (Fig. 1). But to consider open channel flow, one condition has to be satisfied: $5>\mathrm{h}_{0} \geq 0 \mathrm{~m}$ (because height of the conduit is $5 \mathrm{~m}$ ).

For the simplicity of calculations we assume trapezoidal cross section of conduits 3 and 4 only in scenario 1. All conduits in all other examples have circular cross sections. Furthermore, also roughness coefficient in trapezoidal conduits is changed to $\mathrm{Ng}=0.11$ in scenario 1 .

Discharge for open channel flow is calculated after Manning:

$\mathrm{Q}=\frac{\sqrt{\mathrm{I}}}{\mathrm{Ng}} * \frac{\mathrm{A}^{5 / 3}}{\mathrm{P}^{2 / 3}}$

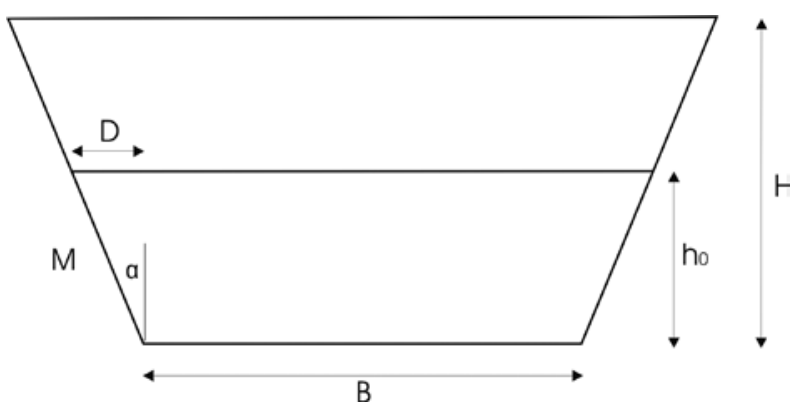

Fig. 4: Cross section of trapezoidal conduit.

Where $\mathrm{A}$ and $\mathrm{P}$ are flow cross section and perimeter of flow. They are given by:

$\mathrm{A}=\mathrm{bh}_{0}+\mathrm{mh}_{0}^{2}$

$\mathrm{P}=\mathrm{b}+2 \mathrm{~s}=\frac{2 \mathrm{~h}_{0}}{\sin \alpha}=\mathrm{b}+2 \mathrm{~h}_{0} \sqrt{1+\mathrm{m}^{2}}$

Where

$\mathrm{m}=\operatorname{tg} \alpha=\frac{\mathrm{D}}{\mathrm{h}}$

see Fig. 4

Values $\mathrm{D}, \mathrm{B}$ and $\mathrm{h}$ are given in tab. 1

And hydraulic gradient I:

$\mathrm{I}=\frac{\Delta \mathrm{H}_{3,4}}{\mathrm{~L}_{3-4}}$

Applying equations (6.), (7.) into equation (5.) we get:

$\mathrm{Q}=\frac{\sqrt{\mathrm{I}}}{\mathrm{Ng}} * \frac{\left(\mathrm{bh}_{0}+\mathrm{mh}_{0}^{2}\right)^{5 / 3}}{\left(\mathrm{~b}+2 \mathrm{~h}_{0} \sqrt{1+\mathrm{m}^{2}}\right)^{2 / 3}}$

Open channel flow through conduits 3 and 4 is possible until recharge $20 \mathrm{~m}^{3} / \mathrm{s}$, according to our calculations. Both conduits fill up with water during higher discharges and full pipe flow occurs. It is described in scenario 2 .

Error as a consequence of simplifying of cross section geometry can be determined. Cross section of trapezoidal conduit (equation 6) should be as possible similar to cross section of circular conduit with diameter $5 \mathrm{~m}$ (Fig. 5). The ratio between cross sections areas is trapezium : circle $=20 \mathrm{~m}^{2}: 19,6 \mathrm{~m}^{2}$. 


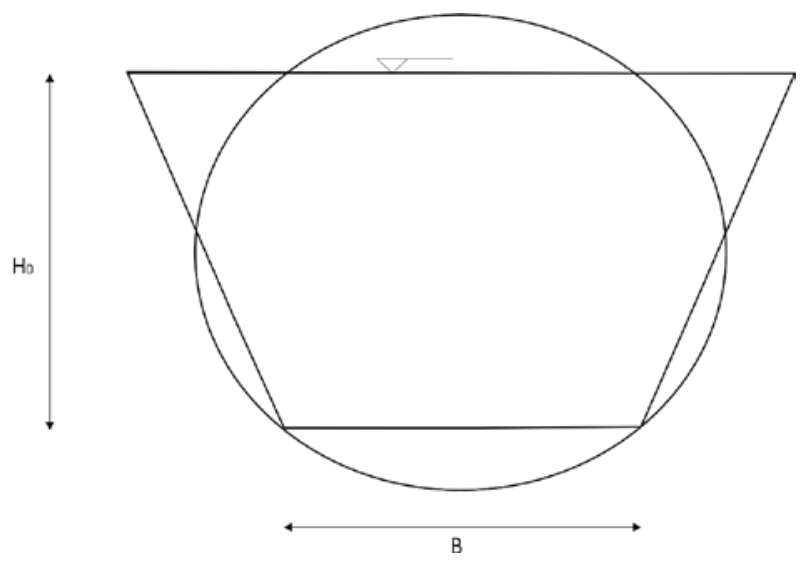

Fig. 5: Trapezoidal and circular cross sections should be similar as possible.

\section{SCENARIO 2: FULL PIPE FLOW THROUGH PRIMARY CONDUITS ONLY}

It is assumed that conduit 2 acts as a reservoir and the water level in it is restricted $30 \mathrm{~m}>\mathrm{h}_{\mathrm{c}}>\Delta \Phi 3$, otherwise water would start to flow through conduit 5 and 6 . Secondary conduits split from the primary at height $\mathrm{h}_{\text {split }}=\mathrm{hc}=30 \mathrm{~m}$ (Fig. 6).

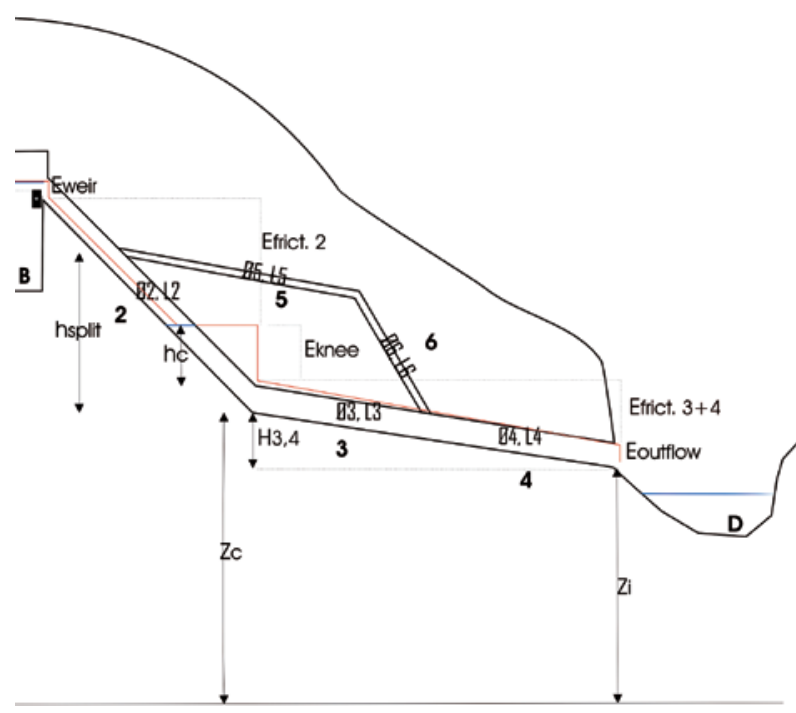

Fig. 6: Shematic review of scenario 2.

We would like to find out the boundary discharge, which causes flow trough secondary conduit (5-6). Also correlation between discharge and water level in conduit $\mathrm{h}_{\mathrm{c}}$ (considering the condition $30 \mathrm{~m}>\mathrm{h}_{\mathrm{c}}>5 \mathrm{~m}$ ) can be de- termined (Fig. 7). First we calculate velocities for selected discharges (using equation (2.): $\mathrm{v}=\frac{\mathrm{Q}}{0,25^{*} \pi^{*}(\Phi)^{2}}$ )

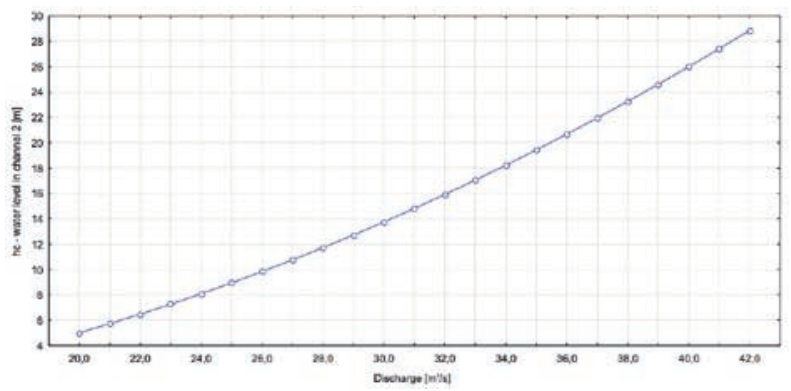

Fig. 7: Relation between water level in conduit 2 and discharge.

and then water level in conduit 2 (value hc) using equation (9.1).

$\mathrm{h}_{\mathrm{c}}+\Delta \mathrm{H}_{3,4}=\Delta \mathrm{E}_{\text {knee }}+\Delta \mathrm{E}_{\text {friction,3-4 }}+\Delta \mathrm{E}_{\text {outflow }}$

$\mathrm{h}_{\mathrm{c}}=\frac{\mathrm{v}^{2}}{2 \mathrm{~g}}\left(\xi_{\text {knee }}+\lambda_{3-4} \frac{\mathrm{L}_{3-4}}{\phi_{3,4}}+\xi_{\text {outflow }}\right)-\Delta \mathrm{H}_{3,4}$

Full pipe flow through conduits 3 and 4 is possible for discharges above $20 \mathrm{~m}^{3} / \mathrm{s}$. Until discharge does not exceed $43 \mathrm{~m}^{3} / \mathrm{s}$, water does not flow through secondary conduits 5 and 6 .

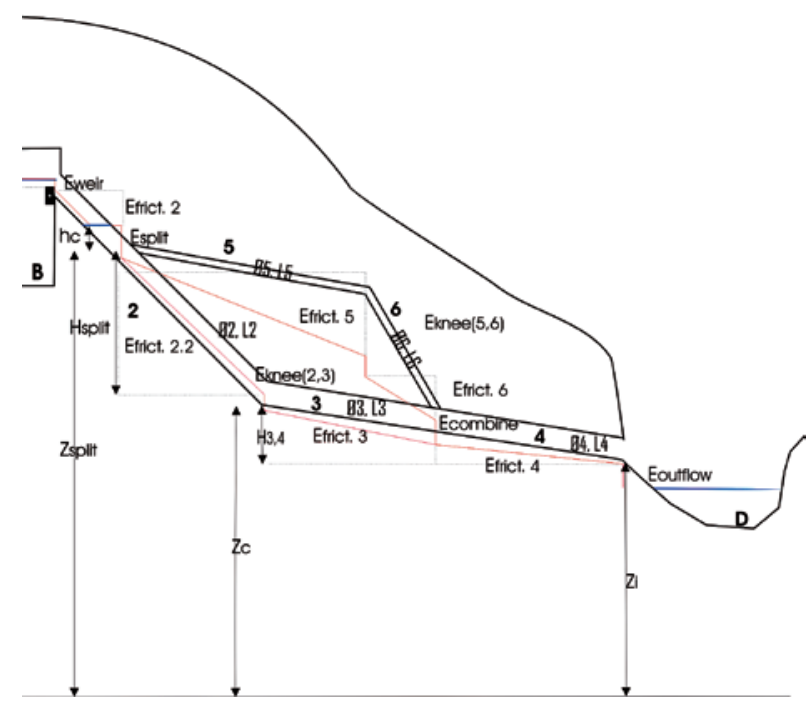

Fig. 8: Shematic review of scenario 3. 


\section{SCENARIO 3: FULL PIPE FLOW THROUGH PRIMARY AND SECONDARY CONDUITS}

The water starts to flow through secondary conduits at discharge $43 \mathrm{~m}^{3} / \mathrm{s}$ (accurately $42.9 \mathrm{~m}^{3} / \mathrm{s}$ ), as was determined in scenario 2. Start of secondary flow should occur at higher discharge in scenario 3, but it does not happen. Water starts to flow through secondary conduits at discharge $41.5 \mathrm{~m}^{3} / \mathrm{s}$ according to calculations in scenario 3 . Reason is in some simplifications, especially in neglecting friction losses within conduit 2 in scenario 2. Friction losses are considered in scenario 3, therefore boundary discharges between two scenarios can not be compared.

Because scenarios 2 and 3 are incompatible, scenario 3 will be used only to find out relation between flow rates in both primary and secondary branches (Fig. 9). It is assumed that the total flow rate exceeds $41.5 \mathrm{~m}^{3} / \mathrm{s}$ and the flow is full pipe in both branches.

Discharges at the spring are considered to be known. Velocities using equation (12.) are calculated first. Velocity $\mathrm{v}_{2-3}$ is in relation with velocity $\mathrm{v}_{5-6}$ (equation 11.3). When velocities are known, equation (2) is used to calculate discharges $\mathrm{Q}_{2-3}$ and $\mathrm{Q}_{5-6}$. Their sum should be equal to the common $\mathrm{Q}$ (equation 10).

Flow splits to two components

$$
\mathrm{Q}=\mathrm{Q}_{2-3}+\mathrm{Q}_{5-6}
$$

Energy drop along both branches (2-3 and 5-6) is equal (Fig. 8)

$\Delta \mathrm{E}_{2-3}=\Delta \mathrm{E}_{5-6}$

$\Delta \mathrm{E}_{\text {friction }, 2.2}+\Delta \mathrm{E}_{\text {knee(2,3) }}+\Delta \mathrm{E}_{\text {friction, } 3}=\Delta \mathrm{E}_{\text {friction, } 5}$

$+\Delta \mathrm{E}_{\text {knee }(5,6)}+\Delta \mathrm{E}_{\text {friction }, 6}+\Delta \mathrm{E}_{\text {combine }}$

$\Delta \mathrm{E}_{\text {combine }}$ was neglected. Applying equations for friction and local losses we get:

$$
\begin{aligned}
& \frac{\mathrm{v}_{2-3}^{2}}{2 \mathrm{~g}} *\left(\lambda_{2-3} * \frac{\mathrm{L}_{2}^{\text {split }}}{\phi_{2}}+\xi_{\text {knee }(2,3)}+\lambda_{3-4} * \frac{\mathrm{L}_{3}}{\phi_{3}}\right)=\frac{\mathrm{v}_{5-6}^{2}}{2 \mathrm{~g}} * \\
& *\left(\lambda_{5-6} * \frac{\mathrm{L}_{5}}{\phi_{5}}+\xi_{\text {knee }(5,6)}+\lambda_{5-6} * \frac{\mathrm{L}_{6}}{\phi_{6}}\right)
\end{aligned}
$$

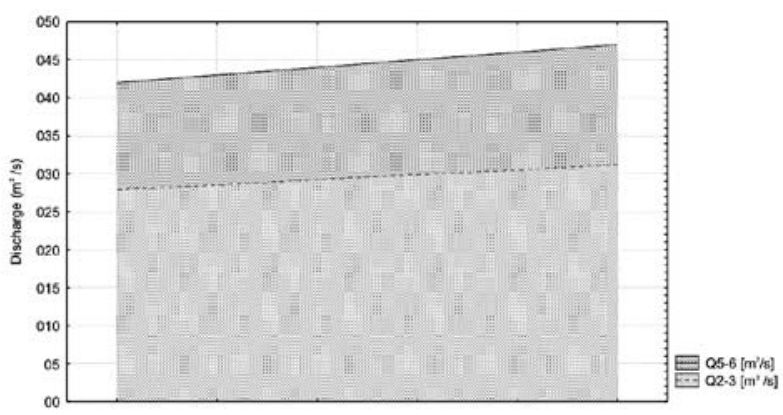

Fig. 9: Comparison of two discharge components through conduits 5-6 and 2-3. Both components present common discharge.

The ratio between velocities $\mathrm{v}_{2-3}$ and $\mathrm{v}_{5-6}$ is written as:

$\mathrm{v}_{2-3}=\sqrt{\frac{\lambda_{2-3} * \frac{\mathrm{L}_{2}^{\text {split }}}{\phi_{2}}+\xi_{\text {knee }(2,3)}+\lambda_{3-4} * \frac{\mathrm{L}_{3}}{\phi_{3}}}{\lambda_{5-6} * \frac{\mathrm{L}_{5}}{\phi_{5}}+\xi_{\mathrm{knee}(5,6)}+\lambda_{5-6} * \frac{\mathrm{L}_{6}}{\phi_{6}}}} * \mathrm{v}_{5-6}=n * \mathrm{v}_{5-6}$

Where symbol $\mathrm{n}$ presents calculated value under the square root.

Employing equation (11.3) and relation $\mathrm{Q}=\pi *\left(\frac{\phi}{2}\right)^{2} * \mathrm{~V} \quad$ in equation (10.) we get

$\mathrm{Q}=\pi *\left(\frac{\phi_{2-3}}{2}\right)^{2} \mathrm{v}_{2-3}+\pi *\left(\frac{\phi_{5-6}}{2}\right)^{2} *\left(\mathrm{n} * \mathrm{v}_{2-3}\right)$

After calculating velocities, equation (12.) can be used to determine discharges $\mathrm{Q}_{2-3}$ and $\mathrm{Q}_{5-6}$.

Proportion of two discharge components is shown in Fig. 9. 


\section{CONCLUSSION}

Geometry of the model had an important role on relation between water level in reservoirs (lake, underground chamber) and discharge through system. Our calculations showed, that water level should rise for about $280 \mathrm{~m}$ to cause flow through secondary conduits 5 and 6 , which is also a consequence of geometry. Unreliable water level indicates that chosen geometry was not optimal.

Scenarios 1 and 2 are used to represent equations for open channel flow and full pipe flow within conduit. When discharge exceeds $20 \mathrm{~m}^{3} / \mathrm{s}$, open channel flow is not possible anymore in conduits 3 and 4 . A lot of simplifications were used especially in scenario 1 , so a difference between boundary discharges at the transition from open channel flow to full pipe flow could be big. To make calculations easier, we assumed a conduit with trapezoidal cross section for open channel flow only (scenario 1), otherwise conduits cross sections are circular. The difference between the two cross sections with different shapes was only two per cents. Problem of misfit results would be more a consequence of a hydraulic jump. It was solved by changing roughness coefficient in trapezoidal conduit (3-4) (scenario 1). Otherwise roughness coefficients were constant in all conduits for all scenarios.

Scenario 3 was used to find out relations between discharges through primary and secondary conduits. Proportion between two discharges is almost 2:1. Discharge, which causes water flow through secondary conduits should exceed $43 \mathrm{~m}^{3} / \mathrm{s}$ or $41.5 \mathrm{~m}^{3} / \mathrm{s}$, depending on neglecting or considering friction losses in conduit 2 .

As can be imagined, model calculations are far from optimal, but they may offer some considerations for modeling karst aquifers.

\section{REFERENCES}

Bonacci, O., 1987: Karst hydrology, with special reference to the Dinaric karst. - Springer - Verlag Berlin Heidelberg.

Campbell, W.C. \& Sullivan, S.M., 2002: Simulating timevarying cave flow and water levels using the Storm Water Management Model. - Engineering Geology 65: 133-139.

Ford, D. \& Williams, P., 1989: Karst geomorphology and hydrology, London.

Halihan, T. \& Wicks, C.M., 1998: Modeling of storm responses in conduit flow aquifers with reservoirs. - Journal of Hydrology 208: 82-91.

Halihan, T., Wicks, C.M. \& Engeln, J.F., 1998: Physical response of a karst drainage basin to flood pulses: example of the Devil's Icebox cave system (Missouri, USA). - Journal of Hydrology 204: 24-36.

Kiraly L., 2002: Karstification and groundwater flow.In Gabrovšek, F. (editor): Evolution of karst: From prekarst to cessation.- ZRC Publishing, Ljubljana.
Rossman, L.A., 2004: Storm water management model User's manual Version 5.0. - EPA United States Environmental Protection Agency, Cincinnati, Ohio.

Sauter, M., 2005: Modelling approaches in karst aquifers - system understanding, characterization and prediction. - 2005 Salt Lake City Annual Meeting (October 16-19, 2005).

Springer, G.S., 2004: A pipe-based, first approach to modeling closed conduit flow in caves. - Journal of Hydrology 289: 178-189.

Steinman, F., 1999: Hidravlika. - Hidrotehnična smer FGG, Ljubljana.

White, W.B., 2003: Conceptual models for karstic aquifers. - Speleogenesis and Evolution of Karst Aquifers, The virtual Scientific Journal, www.speleogenesis.ifo. 
